УДК: 330.33.01:334.021

JEL Classifications: М 21

doi: 10.31767/nasoa.3-2020.02. 08

T. BULAKH,

PhD (Economics), Associate Professor, Associate Professor of Department for Economics and Management of Foreign Economic Activities, e-mail:rla799@ukr.net,

ORCID: 0000-0002-9061-0325,

ResearcherID: K-6198-2018,

L. PLAKHOTNIKOVA,

PhD (Economics), Associate Professor, Associate Professor of Department for Economics and Management of Foreign Economic Activities, National Academy of Statistics, Accounting and Audit, e-mail: lara212010@meta.ua,

ORCID: 0000-0002-9965-878X, ResearcherID: B-1544-2019;

R. HROMADSKYI,

Senior Lecturer,

Cathedra of Organization of Theatre Business named after I. D. Bezhin,

Kyiv National I. K. Karpenko-Kary Theatre,

Cinema and Television University e-mail: gromadskiy@ukr.net,

ORCID: 0000-0001-6575-5744

\title{
Classification of Franchising and Specifics of Its Types in Business Operation
}

The development of business can stuck in a series of problems related with market expansion, recruiting of staff in the dealer network, setting interaction channels etc. These can be dealt with by new economic mechanisms like franchising that allows for increasing the effectiveness of small business. But each of its type has advantages and shortcomings, which, if misunderstood, can cause serious risks to the operation of each partner and business on the whole. The article's objective is to investigate criteria for classification of franchising and business specifics of its types.

It is shown that franchising can take various types and forms in business operation, depending on the classification criteria. A detailed discussion of franchising types is given, classified by character of business operation, opportunities and intentions of franchisee, strategy for franchising business expansion, number of franchising enterprises owned by one franchisee, value of franchise, existence of intermediaries between franchiser and franchisee. It is argued that the above given classification allows one to position franchising types in business operation, choose the most appropriate type of franchising or a type of interactions with partners in creating a franchising enterprise, make projections for franchising-based businesses.

It is emphasized that franchising is not an all-purpose tool for addressing all the problems of small business; it has a great many shortcomings that may be caused by possible dishonesty of a franchiser or rooted in the very nature of franchising. Two groups of shortcomings specific to franchising are discussed in detail. Advantages of the franchising system are demonstrated by comparing statistical data about the firms operated on franchising terms and by traditional methods; by highlighting the significant role of a ready-made standardized business plan provided by a franchiser to a franchisee, which helps insure the latter from business risks; and easy access of an entrepreneur deciding to launch own business (i. e. a franchisee) to bank loans.

Ключові слова: franchising, franchise, franchiser, franchisee, business operation.

(C) T. Bulakh, L. Plakhotnikova, R. Hromadskyi, 2020 
Т. М. БУЛАХ,

кандидат економічних наук, доцент, доцент кафедри економіки та менеджменту зовнішньоекономічної діяльності, e-mail: rla799@ukr.net,

ORCID: 0000-0002-9061-0325,

ResearcherID: K-6198-2018;

Л. О. ПЛАХОТНІКОВА,

кандидат економічних наук, доцент, доцент кафедри економіки та менеджменту зовнішньоекономічної діяльності;

Начіональна академія статистики, обліку та аудиту, e-mail:lara212010@meta.ua,

ORCID: 0000-0002-9965-878X, ResearcherID: B-1544-2019;

Р. А. ГРОМАДСЬКИЙ, стариий викладач

кафедри організації театральної справи імені І. Д. Безгіна, Київький національний університет театру, кіно і телебачення імені I. К. Карпенка-Карого, e-mail: gromadskiy@ukr.net,

ORCID: 0000-0001-6575-5744

\section{Класифікація франчайзингу та особливості його різновидів у підприємницькій діяльності}

В статті досліджено критерії класифікації франчайзингу. Визначено, щуо залежно від них франчайзинг набуває різноманітних видів і форм у підприємницькій діяльності. Виявлено, щзо кожен із різновидів франчайзингу має певні особливості, переваги та недоліки, і вибір конкретної форми визначатиметься стратегією правовласника, умовами ринку, специфікою діяльності, ресурсами та багатьма іншими факторами. Доведено, щзо класифікація франчайзингу дозволяє: визначити роль $i$ місце різновидів франчайзингу в підприємницькій діяльності; иілеспрямовано обрати найбільш ефективну форму або вид взаємин із кожним окремим партнером при створенні франчайзингового підприємства; здійснювати прогнозну оцінку розвитку франчайзингової діяльності.

Ключові слова: франчайзинг, франшиза, франчайзер, франчайзі, підприємниџька діяльність.

Introduction. The development of business in the current economic conditions is affected by a series of problems preventing from the full-fledged utilization of its potentials and capabilities. Businessmen need to expand the market, recruit staff in the dealer network of large firms, set the channels for interactions of small and large businesses. The above problems can be dealt with by new economic mechanisms like franchising that allows for increasing the effectiveness of small business. But each of its categories has advantages and shortcomings. Its misunderstanding can cause serious risks to the operation of each partners and the business on the whole.

Literature review. In domestic and foreign scientific literature problems of franchising have been in focus of researchers in various disciplines, e. g. D. Bayura, G. J. Bolt, M. Dudchenko, J. Evance, D. Kaufmann, A. Kredisov, O. Kuzmin, Ye. Panchenko, J. Stiglitz and others. They elaborate on the essential meaning of the notion "franchising", especially from the perspective of its being a form of international business etc.

Although research on this topic is massive, there are only few domestic works investigating criteria for the franchising classification and business specifics of its type.

The article's objective is to investigate criteria for classification of franchising and business specifics of its types.

Results. Franchising can take various types and forms in business operation, depending on the classification criteria (Figure 1) $[5,7]$. 
By character of business operation of a franchising object:

1. Franchise for commodity manufacturing (commodity franchising) is the distribution of commodities produced by a franchiser under its brand through an extensive trading network of a franchisee. A franchiser increases the sales of its products, expands the geographic coverage of its brand, and ensures the distribution of sales across regions by commissioning certain territories to various franchisees. A franchisee is granted an exclusive right to be a sole distributor of a respective commodity on the territory commissioned to it, and an exclusive representative of the franchiser's brand.

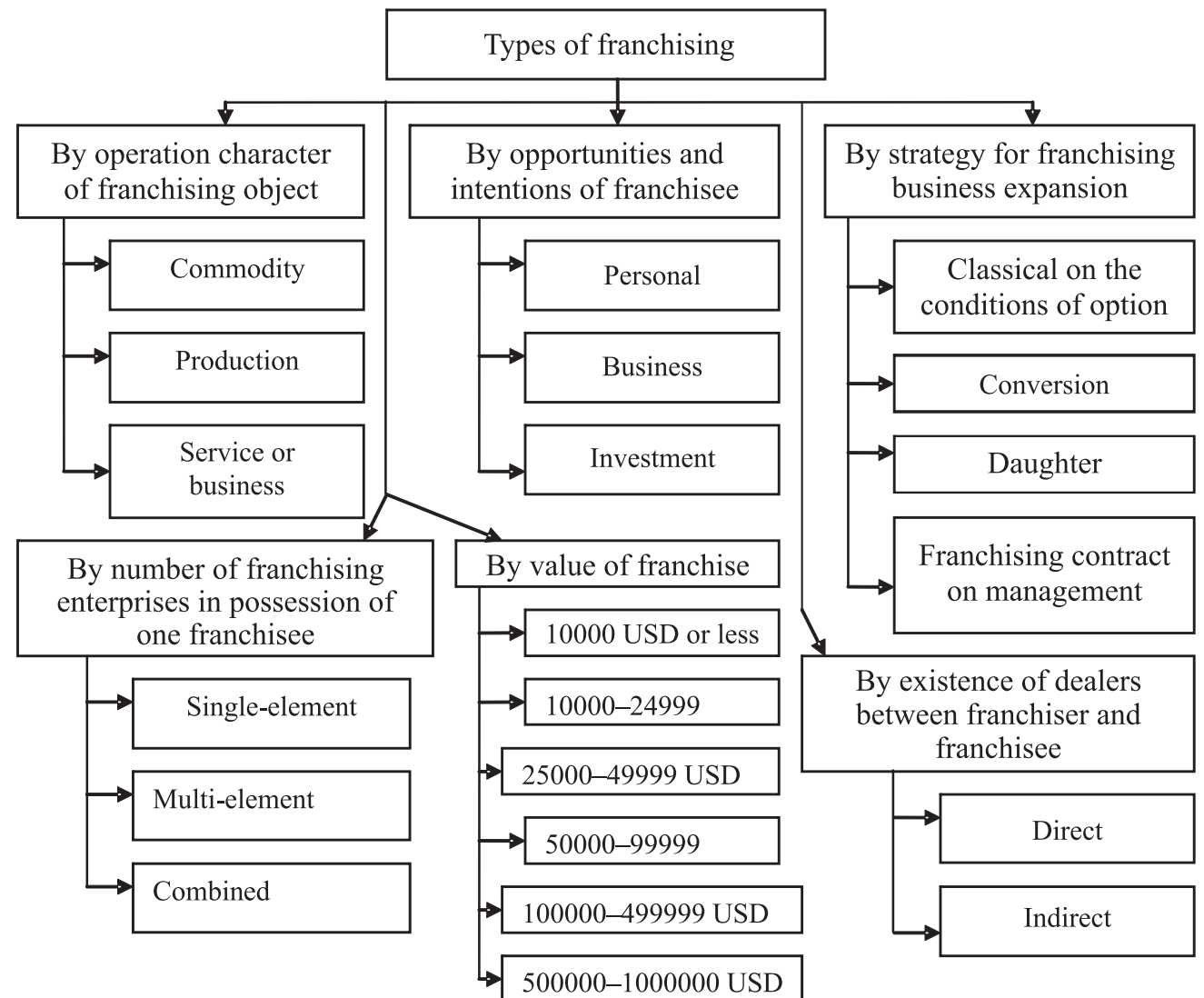

Figure 1. A classification of franchising types

Source: constructed by the authors on the basis of $[5,7]$

The main condition for this type of franchise is that a franchisee pledges to purchase products only from its franchiser, without a permission to sell goods of the same group under competitors' brands. The image of a franchisee is to be formed according to the franchiser's image in order to ensure the brand recognition.

The commodity franchising is the oldest type of franchising, but it remains to be widespread today. Its share tends to exceed $25 \%$ of the total turnover in the franchising sector of the U.S. [10]. It is so because this form of franchising allows franchiser to increase the total sale of its product, whereas the engagement of franchisee in the distribution system and its location on specific territories enables to ensure the even distribution of sales across regions, thus expanding the market geography.

2. Franchise for sales of a finished commodity (production franchising) is a transfer of rights for production and distribution of commodities under the franchiser's brand. In this case a franchiser which is the owner of patented technology for utilization of raw materials and manufacturing of finished products supplies franchisee with these raw materials and transfer it the rights for exploitation of patented technologies for product manufacturing. 
Production franchising is widespread among producers of soft fresh drinks. A well-known example may be the Coca-Cola Company keeping in secret the technology for preparation of concentrates that are part of the drinks and delivering them to franchisee factories for bottling and distribution under its brand.

3. Franchise for a certain activity (service or business franchising). Service franchising is a more sophisticated field, because a franchiser, apart from transferring the right for using the brand, transfers its exclusive technologies, business processes and the method for rendering a certain kind of services. Besides that, this type of franchise may often involve supplies of special software, special literature or internal information to a franchisee.

In case of business franchising, a franchiser transfers a partner not only the distribution rights, but also the license for organization of this type of business.

A franchise strictly specifies business concept, provides instructions on staff training, requirements for the arrangement of factory premises and the staff uniform. Subject to regulation is marketing policy, record-keeping, relationships with commodity suppliers.

Therefore, a franchisee company operates under the brand name of the franchiser firm, and it is obliged to stick to the same concept of business operation. The chief company conducts monitoring of the proper execution of the contract terms.

By opportunities and intentions of franchisee [3, p. 210]:

1. Personal (individual) franchising, typical for individuals with intention to create and operate a sole and very modest franchise business on commodity sales or rendering services just at home or using a transport means. This franchising requires minimal scopes of facilities, stocks of goods or transport means and costs franchisee small money. Incomes from the individual franchising are often modest, being comparable with the earnings of a clerk on similar positions. It means to say that an enterprise like this is just self-supporting.

2. Business franchising is historically linked to family budget, with family members combining the functions of managers and workers. A franchising enterprise for them is the main form of employment and the only source for family income. It is a more expensive enterprise selling goods or rendering services by use of a trade premise analogous to a shop or an office, equipment, machinery, stocks of goods and other assets of a considerable value. It is supposed that financial returns from such franchising business should be much higher than from personal (individual) one.

3. Investment franchising associated with the rise of owners of new types of franchises: companies, investment groups or individuals who are not only willing to invest funds in a given franchise enterprise, but striving to create a regional franchise network using employed staff. The franchise is purchased by a commercial organization seeking for long-term interests on the invested capital rather than only regular incomes.

By strategy for franchising business expansion [4]:

1. Classical franchising on the option conditions, with a franchisee not only receiving a franchise for creating its own enterprise on the stipulated territory, but also the right to open other franchising enterprises under the franchiser's trademark. Apart from the territory granted to a franchisee for future business, a bilateral contract stipulates the number of future franchises and their opening schedule.

2. Conversion franchising. It involves joining of autonomous enterprises with the similar profile to the franchising system "under the umbrella brand of franchiser". The owners of independent enterprises give preference to this way in order to deal with the problems related with advertizing and marketing by using the positive business reputation of a franchiser.

In spite of the increasing financial liabilities with the owners of formerly independent enterprises, the actual business costs may even be reduced due to the decreasing costs for advertizing and marketing programs and the purchases made through the centralized system of a franchiser.

3. Daughter franchising, which is similar to conversion franchising by form. However, unlike the latter, a franchisee is experienced entrepreneur with the already established business. This type of franchising has the following advantages: market penetration on nationwide scales, competitiveness enhancement, benefitting from a well-known trademark, benefitting from research and development. Such entrepreneurs are more independent from a franchiser due to objective reasons. Quite often a franchisee can keep its firm name or use it as a supplementary one. 
4. Franchising contract on management, with a franchisee formally becoming the owner of a franchise enterprise, but actually being only its investor. All the managerial functions being with a franchiser, the role of an official franchisee is only passive.

By number of franchising enterprises owned by one franchisee [7]:

1. One-element franchising. It means that a franchisee is given the right to open only one franchising enterprise by the stipulated address. The franchise granted by a franchiser in case of one-element franchising can be exclusive or non-exclusive. When it is exclusive, a franchisee will have the exclusive right for its exploitation on the stipulated territory. The non-exclusive franchise does not involve this right [11].

2. Multi-element franchising. According to it, a franchisee is given the right to open more than one franchising enterprise on the stipulated territory (their number and location are fixed in the contract terms) [1].

3. Combined franchising. It involves operation of several various franchises (i. e. franchises offered by various franchisers) in the same premise. In doing this, each particular franchisee owns only a part of assets of the business entity [7].

By value of franchise [9]:

1. Below 10000 USD (commercial clearing).

2. 10000-24999 USD (children's education, wedding trips).

3. 25000-49999 USD (clothes and accessories for sports).

4. 50000-99999 USD (foods, printing, networks of coffee houses).

6. 100000-499999 USD (networks of food stores, restaurants, making of banners, outdoor advertizing and signboards);

7. 500000-1000000 USD (networks of hotels, restaurants, fitness).

By existence of intermediaries between franchiser and franchisee [7]:

1. Direct franchising. It involved cooperation of the franchising parties.

2. Indirect franchising. It involves intermediaries to which a franchiser hands over a part of its authorities related to the work with a franchisee.

The above classification allows for:

- determining the significance of forms and types of franchising in business operation;

- making a purposeful choice of the most effective form or type of interactions with each particular partner in creating a franchising enterprise;

- making projections of the franchising development.

However, franchising should not be regarded as an all-purpose tool for addressing all the problems of small business; it has a great many shortcomings that may be caused by possible dishonesty of a franchiser or rooted in the very nature of franchising.

The first group of shortcomings may include:

- a lesser advisory or managerial support from a franchiser than the one stipulated in the contract (which may reduce business profitability of a franchisee and prolong the payback period);

- franchiser's attempts to force a franchisee to give up its business in the franchiser's favor, once the contract is over, instead of the contract prolongation.

The second group of shortcomings may include:

- Uncertain nature of the selection procedure. Franchising is a long-term cooperation of two independent economic actors, involving a procedure for selecting a potential business partner. While for a franchisee this procedure is informal, franchisers tend to make selections by a formalized method with rather high percentage of screening, in order to minimize the risks of failure of a potential franchisee and losses for own image. It means to say that although a newcomer may be interested in a franchise, it may happen that he will not be able to pass the selection procedure and a franchiser will not be willing to sign a contract with him.

- Incompliance between the concept of a franchising network and the preferences of a targeted audience (this risk is the largest when the purchased franchise is a foreign one, initially developed for another market). It implies that a franchisee has not right to make a change in the franchise concept without the franchiser's agreement.

- The risk of loss of the whole business (to protect the intellectual property of a franchiser, standard franchising contracts usually include an article prohibiting a 
franchisee to run the same business on the same territory after the contract term is finished).

However, according to experts, the shortcomings faced by a franchisee are so minor compared with the opportunities and advantages of the franchising technology as a way of business development that most part of small and medium-sized companies prefer to neglect them [2].

Statistical data show that of the total newly created firms in the U.S., $23 \%$ of private firms can survive after five years and only $18 \%$ remain alive after ten years, but of the firms operated by the franchising system, only eight of the hundred collapse after five years, and of the total newly created firms across the world, nearly $90 \%$ in average become bankrupt within three years, whereas for franchising firms this figure is less than $10 \%$ (Figure 2) [6].

Due to franchising a small enterprise has an opportunity to use a well-known trademark for attracting clients, and, besides that, it can essentially increase the business effectiveness though exploiting commercial technologies of a franchiser and its consultative and managerial support (it should be noted that the franchisees that are going to launch business are obliged to be trained by their franchiser). In fact, a franchisee gets access to the franchiser's client base. This can reduce business risks of a franchisee.

Besides that, a franchiser usually has a ready-made standardized business plan that is to be followed by a franchisee. This business plan specifies the size of necessary investments, the expected sales, the estimated payback periods, the sequence of franchisee's actions when launching its business etc. It is clear that a franchiser cannot guarantee that actual business figures of a franchisee will not be lower than the ones stipulated in the business plan, as the franchisee's success depends, above all, on its own effort. However, the franchiser's access to the statistical data on the franchisee's operation gives one all the grounds to say that the actual business figures will comply with the expected ones.

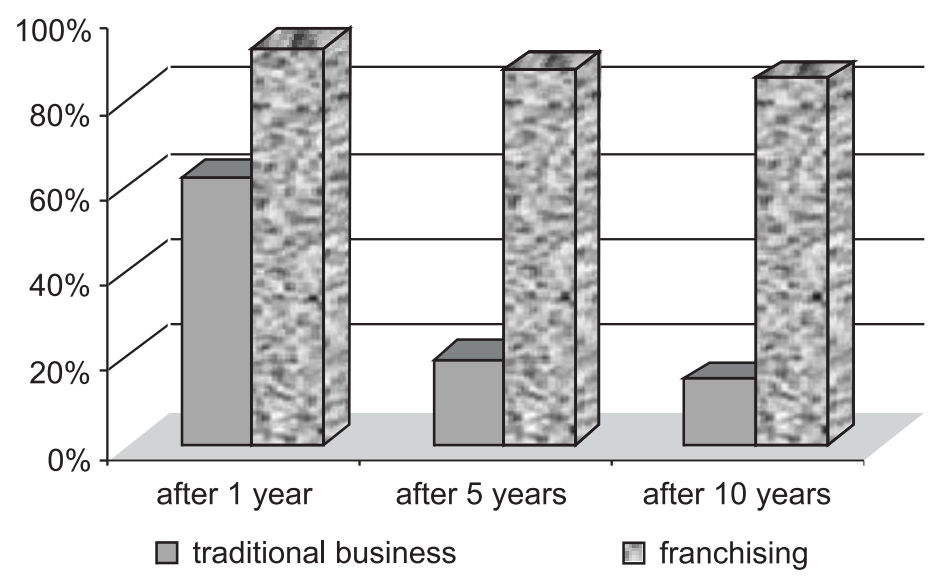

Figure 2. Comparison of the firms operated on franchising terms and by traditional methods

Source: [6]

With this business plan in possession, a franchisee knows what amount of resources and efforts is required to run the business, being insured from unforeseen expenses. It also helps reduce its operation risks.

Another important point is that an entrepreneur who has decided to run business not in a sole manner but within a franchising network can more easily solve another problem pressing a small business entity, which is the access to bank loans. Because franchising can reduce the risks for an entrepreneur, banks are more willing to lend funds for creation and development of franchisee businesses. The list of franchisees with loans has been constantly increasing, and, besides, a potential franchisee which wants to get a loan to open business under the brand of a franchiser without loans can address a bank on its own behalf with a loan application. It should be noted bank loans offer an additional confirmation of the franchiser's fair practice, which helps reduce franchisee's risks. 
Also, there have appeared special investment organizations willing to invest in developing franchisee enterprises.

No doubt that franchising is not a single way to start up own business. A firm can be created without assistance of large networks or can simply be purchased. Like any other way of business operation, franchising has its advantages and shortcomings. And each investor which is willing to create business through franchising needs to scrutinize all the points and decide if it is worth for it to join a network [8].

Conclusions. Cooperation of a franchiser and a franchisee can be referred to as bilateral outsourcing providing a franchisee with franchiser's services in brand management within the franchising network and advisory support of franchisee's business, with a franchiser charging a franchisee with the function of attracting capital for establishing an enterprise under the franchiser's trademark and the function of the current management of this enterprise.

The successful operation of a business built on the franchising system is conditional on the right choice and exploitation of a franchising type, due account to its specificities, advantages, shortcomings and benefits.

Further studies are expected to deal with problems and prospects of franchising activities in the Ukrainian context.

\section{References}

1. Androshchuk S. (2018). Tverdaya vygoda myagkogo franchayzinga [Hard benefits of the soft franchising]. Kompanion - Companion, 26 (282), 42-44 [in Russian].

2. Vasylchyshyn O. Problemy rozvytku franchaizynhovoho mekhanizmu v Ukraini [Problems of development of franchising mechanism in Ukraine]. Retrieved from dspace. tneu.edu.ua bitstream/316497. [in Ukrainian].

3. Zabelin P. E. (2011). Osobennosti mezhdunarodnogo franchayzinga [Features of international franchising]. Proceedings from: I mezhdunar. nauch. konf. "Gosudarstvo i pravo: teoriya i praktika" - The 1st Scientific Conference "State and law: theory and practice". (pp. 207-212). Chelyabinsk [in Russian].

4. Kats R. B. Franchayzing: postroenie predpriyatiya, buhgalterskiy uchet, pravovyie aspektyi [Franchising: company building, accounting, legal aspects]. Retrieved from https://textarchive.ru/c-1277474-p3.html. [in Russian].

5. Kolesnikov V. (2013). Postroenie franchayzingovogo biznesa: Kurs dlya pravoobladateley i polzovateley franshiz: nauchnoe izdanie [Building a Franchise Business: A Course for Franchise Owners and Users: Scientific Edition]. Piter: Spb [in Russian].

6. Korsak V. Franchaizynh - efektyvnyi sposib orhanizatsii rozdribnoi torhivli ta stymuliuvannia rozvytku ekonomiky rehioniv [Franchising: an effective way of organizing retail trade and stimulating the development of the economy of the regions]. Retrieved from http://nbuv.gov.ua/UJRN/econ_2012_8_15. [in Ukrainian].

7. Kuzmin O. Ye., Myronchuk T. V., Salata I. Z., Marchuk L. V. (2011). Franchaizynh [Franchising]. Kyiv: Znannia [in Ukrainian].

8. Mavridu V. Yu. Teoretychni ta praktychni aspekty franchaizynhu [Theoretical and practical aspects of franchising]. Retrieved from http://sapr.ru/Archive/SG/2002/6/10/\#01\#01. [in Ukrainian].

9. Riznovydy franchaizynhu [Types of franchising]. Retrieved from https://studexpo. $\mathrm{ru} / 133365 /$ turizm/raznovidnosti_franchayzinga. [in Ukrainian].

10. Ustyuzhanin A. A. (2010). Zārubezhnyiy opyit i rossiyskaya praktika razvitiya franchayzinga [Foreign experience and Russian practices of franchising development]. Abstract of PhD thesis. Moskow [in Russian].

11. Tsyrat A. (2012). Franchaizynh ta franchaizynhovyi dohovir [Franchising and franchising agreement]. Kyiv: Istyna [in Ukrainian].

\section{Bibliographic description for quoting:}

Bulakh T., Plakhotnikova L., Hromadskyi R. (2020). Classification of Franchising and Specifics of Its Types in Business Operation. Scientific Bulletin of National Academy of Statistics, Accounting and Audit - Naukovyy visnyk Natsionalnoi akademiyi statystyky, obliku ta audytu, 3, 77-83. doi: 10.31767/nasoa.3-2020.08. 